\title{
Dental abnormalities of the southern thorny skate Amblyraja doellojuradoi (Chondrichthyes, Rajidae)
}

Anomalías dentarias de la raya erizo Amblyraja doellojuradoi (Chondrichthyes, Rajidae)

\author{
Gabriela Delpiani $^{1,2}$, Daniel E. Figueroa ${ }^{1}$ and Ezequiel Mabragañaa ${ }^{1,2}$
}

\author{
${ }^{1}$ Departamento de Ciencias Marinas, Facultad de Ciencias Exactas y Naturales, Universidad Nacional de Mar del Plata, Funes \\ 3350, Mar del Plata (B7602AYL), Argentina. gabriela.delpiani@gmail.com \\ ${ }^{2}$ Consejo Nacional de Investigaciones Científicas y Técnicas (CONICET), Argentina
}

\begin{abstract}
Teeth morphology has been widely used in taxonomic, biological and fossil teeth studies of Chondrichthyes. Herein, dental abnormalities in Amblyraja doellojuradoi are described. Almost $10 \%$ of 182 specimens sampled presented any of these types of dental anomalies: (1) an additional incomplete tooth row between two complete rows, (2) an increasing tooth base size and division of its cusps until the complete splitting of teeth in the same row, and (3) an irregular tooth arrangement on the right side of the lower jaw. Possible causes producing these malformations such as mutation, damage by feeding or reproductive behavior are discussed.
\end{abstract}

Key words: Teeth, malformation, Southern Atlantic

\section{INTRODUCTION}

The genus Amblyraja Malm, 1877 consists of 10 species characterized by having a very rough dorsal disc with scattered coarse spinules and strong thornlets. Amblyraja doellojuradoi (Pozzi, 1935), inhabits the Southwest Atlantic (SWA) (Menni \& Stehmann 2000) and the Southeastern Pacific Ocean (Lamilla \& Bustamante 2005). In the Argentinean continental shelf, it is distributed from $35^{\circ}$ to $56^{\circ} \mathrm{S}$, between $51-642 \mathrm{~m}$ of depth and $2-7^{\circ} \mathrm{C}$. Information on the southern thorny skate is scarce and it refers almost exclusively to its taxonomy and distribution (Menni \& Stehmann 2000, Cousseau et al. 2007). A brief description of $A$. doellojuradoi diet was provided by Sanchez and Mabragaña (2002).

Teeth morphology is an important tool widely used in taxonomic, biological and fossil teeth studies of cartilaginous fishes (Herman et al. 1994, 1995, 1996, Kemp 1999, Adnet \& Cappetta 2001, Sáez \& Lamilla 2003). According to the consumed prey, chondrichthyan's teeth may take different forms which are attributed to different functions (Motta 2004). On the other hand, variations in tooth morphology may indicate any kind of malformation. Abnormal teeth were recognized and distinguished from normal teeth in terms of morphological attributes that lied outside the range of normal tooth variation (Becker et al. 2000). These phenomena have been reported in sharks but rarely in skates (Gudger 1933, Sáez \& Lamilla 2003). In fact, in the most exhaustive reports of skate tooth morphology made by Herman et al. (1994, 1995, 1996), who described and illustrated dentition of representatives of 26 different genus worldwide, but nothing about teeth malformation was reported.

Given the paucity of information on teeth malformation in skates, the purpose of this study was to provide a qualitative description of the dentition and a detail depiction of three types of malformations found in Amblyraja doellojuradoi dentition.

\section{Materials ANd Methods}

A total of 182 specimens were collected from research cruises carried out by the National Institute of Fisheries Research and Development in the Argentinean continental shelf from $36^{\circ}$ to $47^{\circ} \mathrm{S}$ from 2005 to 2010 . Total length (TL) and disc width (DW) of each skate were measured to the nearest millimeter ( $\mathrm{mm}$ ), and weight to the nearest gram $(\mathrm{g})$. Sex of each animal was recorded. The maturity status of each individual was registered following Stehmann (2002).

Skates were identified as $A$. doellojuradoi through Cousseau et al. (2007), not presenting any visible abnormality. Jaws were extracted, cleaned and prepared with two different treatments. Thirty five of them were dried and whitened with $30 \%$ diluted hydrogen peroxide, while the tooth plates of the rest were excised and pasted 
onto a vegetal paper. The number of teeth rows in the upper and lower jaws of each specimen was counted from the symphysial (1) to the commissural tooth (n) of each half jaw.

\section{Results AND Discussion}

A dentition with gradient monognathic heterodonty was observed in A. doellojuradoi, which means that teeth from the same row are morphologically different. Also presents ontogenetic heterodonty, having the juveniles little developed cusps, and adults well developed and sharp-pointed cusps. This difference was manifest in males and females, although it was more evident in the former. Finally, in this species sexual heterodonty was observed; males presented more developed, erect and pointed crowns than females. Crown bases were semioval in females and rather circular in males. Further, tooth rows were sharper, and more separated one from another in males than in females (Fig. 1). The number of rows in the upper jaw was 27 to $36($ mean= 31.29) and in the lower was 26 to $34($ mean $=30.36)$. Contrasting the general characteristics of the teeth of the southern thorny skate, some anomalous teeth were found.

Three types of anomalies were observed in 18 specimens of $A$. doellojuradoi, representing $9.9 \%$ of all analyzed specimens ( $\mathrm{n}=182)$ (Table 1): (1) an additional incomplete tooth row between two complete rows, (2) an increasing tooth base size and division of its cusps until the complete splitting of teeth in the same row, and (3) an irregular tooth disposition.

Table 1. Details of specimens bearing dental anomalies. Anomalies types were: (1) an additional incomplete tooth row between two complete rows, (2) an increasing tooth base size and division of its cusps until the complete splitting of teeth in the same row, and (3) an irregular tooth disposition. *: indicates the rows where the incomplete row is located. X: Indicate in which jaw (upper or lower) is the irregular disposition / Datos de los especímenes que tienen anomalías dentales. Los tipos de malformación fueron: (1) una hilera incompleta adicional entre dos hileras completas, (2) el aumento del tamaño de la base de los dientes y división de sus cúspides, hasta que este se divide por completo formando dos hileras y (3) una disposición irregular de los dientes. *: Indica entre que hileras se encuentra la hilera incompleta. X: Indica en que mandíbula (superior o inferior) los dientes se encuentran dispuestos irregularmente

\begin{tabular}{|c|c|c|c|c|c|c|c|c|}
\hline $\begin{array}{c}\text { Dental } \\
\text { Anomaly }\end{array}$ & $\begin{array}{c}\text { Specimen } \\
\text { number }\end{array}$ & $\begin{array}{c}\text { Total length } \\
(\mathrm{mm})\end{array}$ & Sex & $\begin{array}{l}\text { Maturity } \\
\text { stage }\end{array}$ & $\begin{array}{l}\text { Number } \\
\text { Upper jaw }\end{array}$ & $\begin{array}{l}\text { of rows } \\
\text { Lower jaw }\end{array}$ & $\begin{array}{l}\text { Row of the } \\
\text { Upper jaw }\end{array}$ & $\begin{array}{l}\text { anomaly } \\
\text { Lower jaw }\end{array}$ \\
\hline \multicolumn{9}{|c|}{ Anomaly type 1} \\
\hline & 1 & 491 & Male & Mature & 34 & 31 & $1-2$ left* & \\
\hline & 2 & 538 & Male & Mature & 34 & - & & $1-2$ left* \\
\hline & $3-3^{\prime}$ & 473 & Female & Mature & 31 & 29 & $1-2$ left* & 4-5 left* \\
\hline & $4-4$ & 460 & Female & Mature & 38 & - & $\begin{array}{l}\text { 6-7 right* } \\
\text { and } \\
2-3 \text { left* }\end{array}$ & \\
\hline & 5 & 505 & Female & Mature & 31 & 31 & 11-12left* & \\
\hline & 6 & 498 & Female & Mature & 34 & 34 & 1-2 left* & \\
\hline \multicolumn{9}{|c|}{ Anomaly type 2} \\
\hline & 7 & 475 & Male & Mature & 32 & 31 & 4 left & \\
\hline & 8 & 462 & Male & Mature & 33 & 32 & 8 left & \\
\hline & 9 & 509 & Male & Mature & 31 & 29 & 5 left & \\
\hline & 10 & 496 & Male & Mature & 35 & 32 & 1 right & \\
\hline & 11 & 521 & Male & Mature & 35 & 32 & $11 \mathrm{left}$ & \\
\hline & 12 & 437 & Male & Mature & 30 & 30 & 5 right & \\
\hline & $13-13^{\prime}$ & 400 & Female & Immature & 34 & 32 & 1 & 1 \\
\hline & 14 & 452 & Female & Mature & 32 & 28 & & 1 \\
\hline & 15 & 458 & Female & Mature & 32 & 29 & & 11 right \\
\hline & 16 & 470 & Female & Mature & 33 & 31 & & 15 left \\
\hline \multicolumn{9}{|c|}{ Anomaly type 3} \\
\hline & 17 & 514 & Female & Mature & 30 & - & & $\mathrm{X}$ \\
\hline & 18 & 476 & Male & Mature & 30 & 27 & & $X$ \\
\hline
\end{tabular}




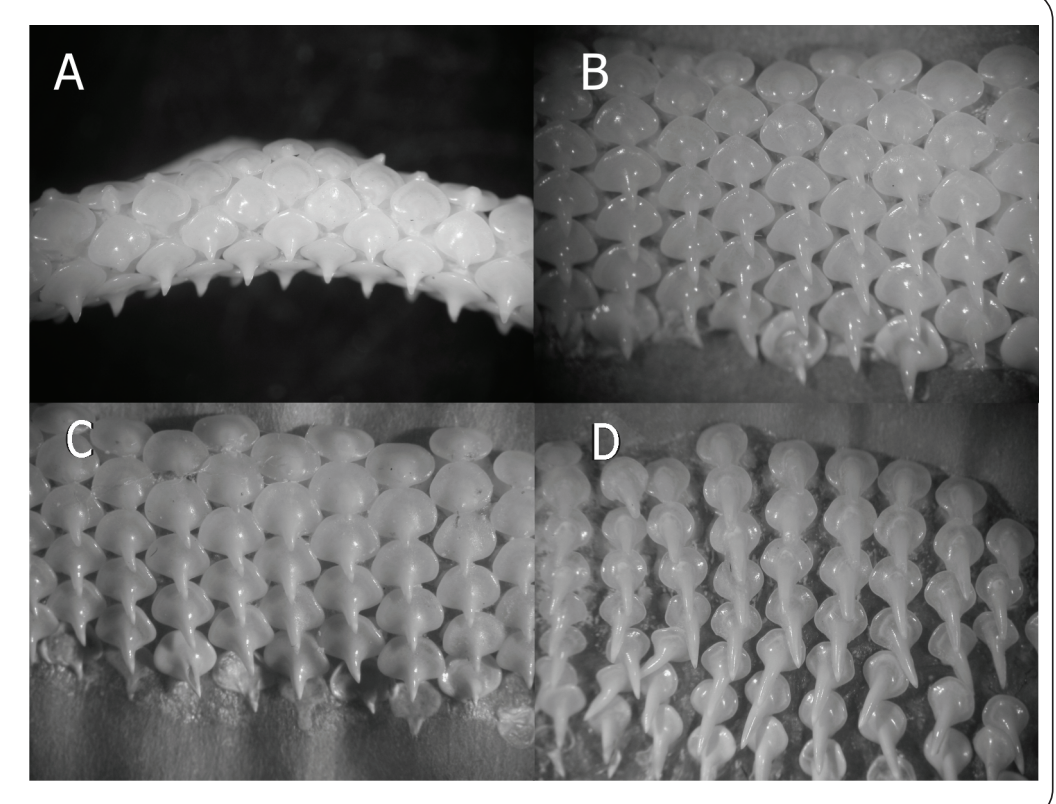

Figure 1. Jaws of the specimens without dental anomalies. A) Immature female (390 $\mathrm{mm} \mathrm{TL})$, B) Mature female (515 $\mathrm{mm} \mathrm{TL}), C)$ Immature male (396 mm TL) and D) Mature male (516 mm TL). Bar scale $=15 \mathrm{~mm} /$ Mandíbulas de los especímenes sin anomalías dentales. A) Hembra inmadura (390 mm LT), B) Hembra madura (515 mm LT), C) Macho inmaduro (396 mm LT) y D) Macho maduro (516 mm LT). Barra de escala $=15 \mathrm{~mm}$

The specimens that belonged to the first group of jaw anomaly were two males and four females (Table 1). In these jaws, a file having teeth mostly smaller than normal, emerging from the inner to the outer face of the jaw, between two normal files was observed (Fig. 2A). The specimens that belonged to the second group of type anomaly were 6 males and 4 females. All males were sexually mature, while females were both immature and mature (Table 1). Bicuspid teeth were located as the first or last tooth of the row and from them two rows were arisen or continued with a single one (Fig. 2B). The anomaly was found mainly in upper jaw (Table 1). The third type of anomaly was observed in two specimens, a male and a female, in which a malformation in the lower jaw was presented. Basically, the teeth had underdeveloped cusps and deformed bases. This anomaly was observed on the left side of the inferior jaw (specimen \# 17), and on the labial face of the jaw (specimen \# 18) (Fig. 2C). In the later specimen, also an abnormal row arrangement was observed.

The most common tooth anomaly recorded for chondrichthyans was the division of teeth and rows (Gudger 1937). This kind of anomaly was found in some sharks, like Heterodontus sp., the blacktip reef shark, Carcharhinus melanopterus (Quoy and Gaimard, 1824) and the dusky shark, Carcharhinus obscurus (Lesueur, 1818) (Gudger 1937), but was never reported in skates, except in the present report for A. doellojuradoi. However, Reif (1980) stated that splitting could be the standard process for adding new tooth families and not a malformation. The scarce dental anomalies recorded for skates were size reduction and variation in tooth shape in the thornback ray, Raja clavata (Linnaeus, 1758) and in the barndoor skate, Dipturus laevis (Mitchill, 1818) (Gudger 1933), as well as teeth size reduction in a female of the graytail skate, Bathyraja griseocauda (Norman, 1937) (Sáez \& Lamilla 2003).

According to Becker et al. (2000), two classes of teeth malformation can be observed: those involving the entire row and those that were limited to only one tooth. In the first case a long-term agent that inhibits normal production of the tooth (mutation) could be acting. The second case implied a short-term cause which was later corrected by some process of healing (Becker et al. 2000). The aforementioned author proposed some possible explanation for tooth anomalies in chondrichthyans, involving vital effects like injury, disease and mutation that act during the life of an animal. Damage suffered by chondrichthyans during feeding could produce a variety of dental deformities (Becker et al. 2000). Gudger (1937), Hubbell (1996) and Becker et al. (2000) clearly showed how the spines from the ray's tails and bony fishes, when were consumed by sharks, could damage their tissue producing teeth malformations. However, the damage 

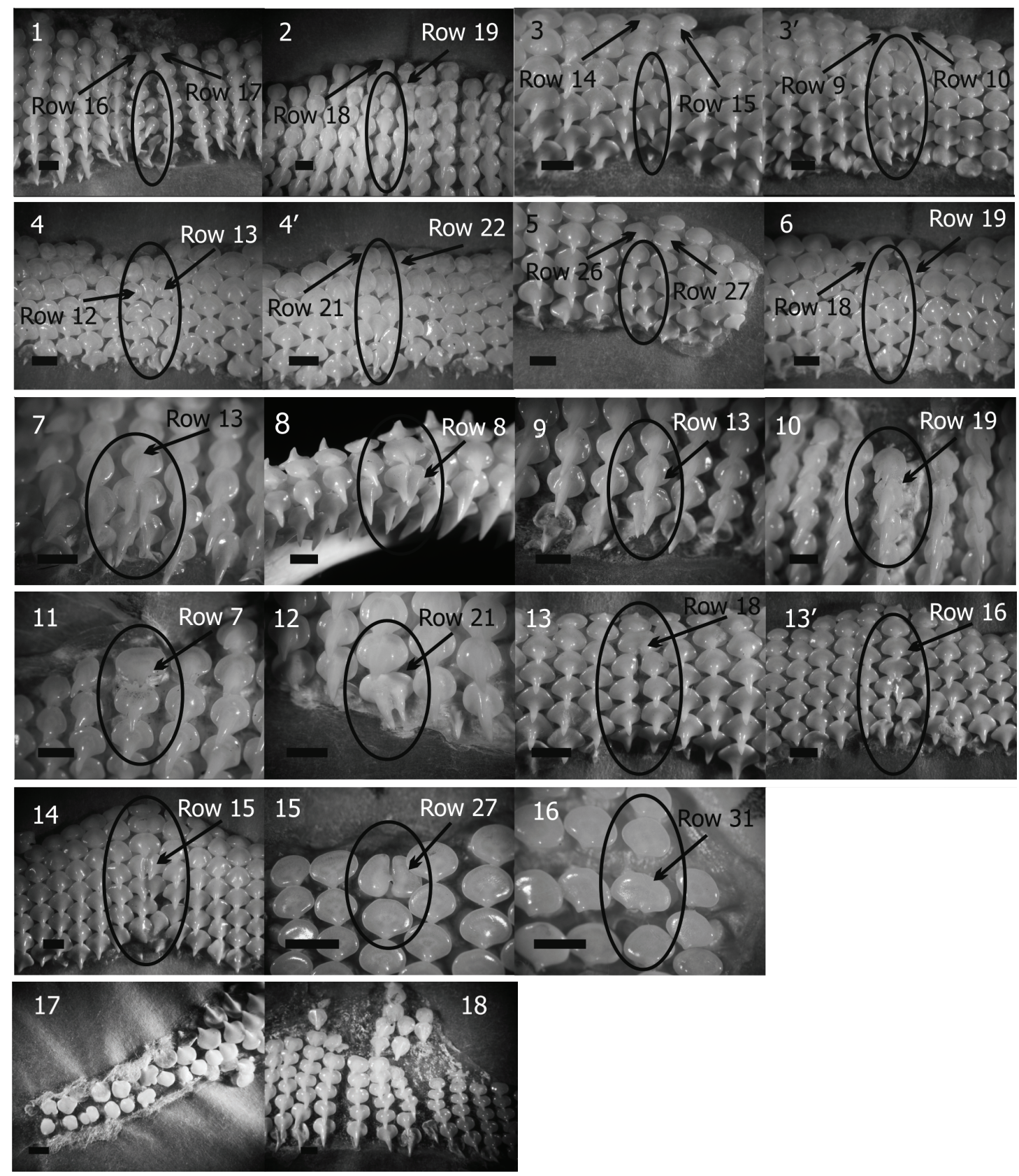

Figure 2. Jaw anomalies: A) Specimens 1 to 6, with the first type of jaw anomaly; B) Specimens, 7 to 16 , with the second type of jaw anomaly; C) Specimens, 17 and 18, with the third type of jaw anomaly. Numbers of the specimens according to Table 1 . Bar scale= 15 mm / Anomalías mandibulares: A) Especímenes 1-6 que poseen el primer tipo de anomalía; B) Especímenes 7-16 que poseen el segundo tipo de anomalía; C) Especímenes 17 y 18 que poseen el tercer tipo de anomalía. Los números de especímenes corresponden a los indicados en la Tabla 1. Barra de escala $=15 \mathrm{~mm}$ 
occurred during feeding did not rule out the possibility of some genetic mutation, producing some anomalies. On the other hand, it is known that during copulation skates bite to grip (Luer \& Gilbert 1985); therefore, in species with robust spines on the dorsal face, bitting could provoke damage in their jaws.

The causes of the anomalies described for Amblyraja doellojuradoi are unknown. Based on what was previously discussed, the malformations could be attributed to mutations, damage by feeding or copulation or a standard process for adding new tooth families. In specimens of $A$. doellojurado $i$ with the first type of anomaly, the malformation involved the entire file. Therefore, the cause could be a mutation or simply splitting. In those with the second type of malformation, besides the previous causes, jaw injury in some life time should not be avoided. In specimens with the third type of anomaly, malformation clearly seemed to be the result of jaw tissue damage. A. doellojuradoi fed mainly on crabs and their hard exoskeleton could generate some tissue injury. On the other hand, since this species distinctively posses robust spines on the dorsal face this could provoke jaw injuries during copulation. However, there is no strong evidence that these causes are dominant in producing the anomalies described for $A$. doellojuradoi.

Further analysis regarding behavior during feeding and copulation, as well as histological studies on damaged tissues are needed to understand some of the anomalies described here. In addition, it would be of major importance to analyze if splitting is the consequence of mutation or a natural process of adding teeth rows, taking into account that this process has never been reported in skates so far and may play an important role in skate tooth development.

\section{LITERATURE CITED}

Adnet S \& H Cappetta. 2001. A palaeontological and phylogenetical analysis of squaliform sharks (Chondrichthyes: Squaliformes) based on dental characters. Lethaia 34: 234248.

Becker MA, JA Chamberlain \& PW Stoffer. 2000. Pathologic tooth deformities in modern and fossil chondrichthyans: a consequence of feeding-related injury. Lethaia 33: 103-118.

Cousseau MB, DE Figueroa, JM Díaz de Astarloa, E Mabragaña \& LO Lucifora. 2007. Rayas, chuchos y otros batoideos del Atlántico Sudoccidental $\left(34^{\circ} \mathrm{S}-55^{\circ} \mathrm{S}\right)$, 102 pp. Publicaciones Especiales INIDEP, Mar del Plata.
Gudger EW. 1933. Abnormal dentition in rays, Batoidei. Journal of the Elisha Mitchell Scientific Society 49: 57-96.

Gudger EW. 1937. Abnormal dentition in sharks, Selachii. Bulletin of the American Museum of Natural History 73: 249-280.

Herman J, M Hovestadt-Euler, DC Hovestadt \& M Stehmann. 1994. Part B: Batomorphii $\mathrm{N}^{\circ} 1 \mathrm{a}$ : Order Rajiformes- Suborder Rajoidei- Family: Rajidae-Genera and subgenera: Anacanthobatis (Schroederobatis), Anacanthobatis (Springeria), Breviraja, Dactylobatus, Gurgesiella (Gurgesiella), Gurgesiella (Fenestraja), Malacoraja, neoraja and Pavoraja. Contributions to the study of the comparative morphology of teeth and other relevant ichthyodorulites in living supra-specific taxa of chondrichthyans fishes. Bulletin de L'Institut Royal des Sciences Naturelles de Belgique, Biologie 64: 165-207.

Herman J, M Hovestadt-Euler, DC Hovestadt \& M Stehmann. 1995. Part B: Batomorphii $\mathrm{N}^{\circ} 1 \mathrm{~b}$ : Order Rajiformes- Suborder Rajoidei- Family: Rajidae-Genera and subgenera: Bathyraja (with a deep-water, shallow-water and transitional morphotype), Psammobatis, Raja (Amblyraja), Raja (Dipturus), Raja (Leucoraja), Raja (Raja), Raja (Rajella) (with two morphotypes), Raja (Rioraja), Raja (Rostroraja), Raja lintea, and Sympterygia. Contributions to the study of the comparative morphology of teeth and other relevant ichthyodorulites in living supraspecific taxa of chondrichthyans fishes. Bulletin de L'Institut Royal des Sciences Naturelles de Belgique, Biologie 65: 237-307.

Herman J, M Hovestadt-Euler, DC Hovestadt \& M Stehmann. 1996. Part B: Batomorphii $\mathrm{N}^{\mathrm{o}} 1 \mathrm{c}$ : Order Rajiformes- Suborder Rajoidei- Family: Rajidae-Genera and subgenera: Arhynchobatis, Bathyraja richardsoni-type, Cruriraja, Irolita, Notoraja, Pavoraja (Insentiraja), Pavoraja (Pavoraja), Pseudoraja, Raja (Atlantoraja), Raja (Okajamei) and Rhinoraja. Contributions to the study of the comparative morphology of teeth and other relevant ichthyodorulites in living supra-specific taxa of chondrichthyans fishes. Bulletin de L'Institut Royal des Sciences Naturelles de Belgique, Biologie 66: 179-236.

Hubbell G. 1996. Using tooth structure to determine the evolutionary history of the white shark. In: Klimley AP \& DG Ainley (eds). Great white sharks: the biology of Carcharodon carcharias, pp. 9-18. Academic Press, San Diego.

Kemp NE. 1999. Integumentary system and teeth. En: Hamlett WC (ed). Sharks, skates and rays, pp. 43-68. Johns Hopkins University Press, Baltimore.

Lamilla J \& C Bustamante. 2005. Guía para el reconocimiento de: tiburones, rayas y quimeras de Chile. Oceana 17 (2005): $1-80$. 
Luer CA \& PW Gilbert. 1985. Mating behavior, egg deposition, incubation period and hatching in clearnose skate Raja eglanteria. Environmental Biology of Fishes 13: 161-171.

Menni RC \& MF Stehmann. 2000. Distribution, environment and biology of batoid fishes of Argentina, Uruguay and Brazil. A review. Revista del Museo Argentino de Ciencias Naturales Bernardino Rivadavia 2(1): 69-109.

Motta PJ. 2004. Prey capture behavior and feeding mechanics of elasmobranchs. En: Carrier JC, JA Musick \& MR Heithaus (eds). Biology of sharks and their relatives, pp. 165-202. CRC Press, Florida.

Reif WE. 1980. A mechanism for tooth pattern reversal in sharks: the polarity switch model. Roux's Archives of Developmental Biology 188: 115-122.
Sáez SB \& JF Lamilla. 2003. Sexual homodonty in Bathyraja griseocauda (Norman, 1937) from the Southern Eastern Pacific (Chile) (Chondrichthyes, Rajidae: Arhynchobatinae). Journal of Applied Ichthyology 20(3): 189-193.

Sánchez F \& E Mabragaña. 2002. Características biológicas de algunas rayas de la región sud patagónica. INIDEP, Informe Técnico 48: 1-15.

Stehmann MFW. 2002. Proposal of a maturity stages scale for oviparous and viviparous cartilaginous fishes (Pisces, Chondrichthyes). Archive of Fishery and Marine Research 50: 23-48.

Received 15 February 2011 and accepted 17 November 2011 